ORNL-TM-3870

(ENDF-169)

(Revised)

\title{
SDT4. SODIUM BROOMSTICK EXPERIMENT- AN EXPERIMENTAL CHECK OF NEUTRON TOTAL CROSS SECTIONS
}

\author{
R. E. Maerker
}

\section{OAK RIDGE NATIONAL LABORATORY}




\section{DISCLAIMER}

This report was prepared as an account of work sponsored by an agency of the United States Government. Neither the United States Government nor any agency Thereof, nor any of their employees, makes any warranty, express or implied, or assumes any legal liability or responsibility for the accuracy, completeness, or usefulness of any information, apparatus, product, or process disclosed, or represents that its use would not infringe privately owned rights. Reference herein to any specific commercial product, process, or service by trade name, trademark, manufacturer, or otherwise does not necessarily constitute or imply its endorsement, recommendation, or favoring by the United States Government or any agency thereof. The views and opinions of authors expressed herein do not necessarily state or reflect those of the United States Government or any agency thereof. 


\section{DISCLAIMER}

Portions of this document may be illegible in electronic image products. Images are produced from the best available original document. 
This report was prepared as an account of work sponsored by the United States Government. Neither the United States nor the United States Atomic Energy Commission, nor any of their employees, nor any of their contractors, subcontractors, or their employees, makes any warranty, express or implied, or assumes any legal liability or responsibility for the accuracy, completeness or usefulness of any information, apparatus, product or process disclosed, or represents that its use would not infringe privately owned rights. 
ORNL-TM-3870

(ENDF-169)

(Revised)

Contract No. W-7405-eng-26

Neutron Physics Division

SDT4. SODIUM BROOMSTICK EXPERIMENT - AN EXPERIMENTAL CHECK OF NEUTRON TOTAL CROSS SECTIONS

R. E. Maerker

Reference: E. A. Straker, "Experimental Evaluation of Minima in the Total Neutron Cross Sections of Several Shielding Materials," ORNL-TM-2242 (1968).

SEPTEMBER 1972

This report was prepared as an account of work sponsored by the United States Government. Neither the United States nor the United States Atomic Energy Commission, nor any of their employees, nor any of their contractors, subcontractors, or their employees, makes any warranty, express or implied, or assumes any legal liability or responsibility for the accuracy, comlegal liability or responsibility for the accuracy, com product or process disclosed, or represents that its use would not infringe privately owned rights.

OAK RIDGE NATIONAL LABORATORY

Oak Ridge, Tennessee 37830 operated by

Union Carbide Corporation

for the

U. S. ATOMIC ENERGY COMMISSION 



\section{Abstract}

The experimental and calculational details for a CSEWG integral data testing shielding experiment are presented. 


\section{Description}

This experiment was designed to test a given set of neutron total cross sections for sodium in the range $0.8-11.0 \mathrm{MeV}$. Figure 1 shows a schematic of the arrangement. The sodium sample was a cylinder approximately 4 in. in diameter and placed so that its axis coincided with the axis of the neutron beam. The sample was placed in a stainless-steel container. In order to reduce the effect of neutron inscattering in the sample, the distance from the neutron source (the Tower Shielding Reactor II) to the sample was $50 \mathrm{ft}$ and the detector was $50 \mathrm{ft}$ from the sample. The neutron beam was confined to a diameter of 3.5 in. by collimators placed between the reactor and sample near the sample position. To reduce air-scattering effects the reactor and detector were shielded with lead and water and the reactor beam and detector acceptance were tightly collimated.

The detector was a nominal 2 in. $\times 2$ in. NE-213 scintillator. Separation of neutron- and gamma-induced pulses was made by a modified Forte circuit. Throughout this experiment, a 2-in.-thick sample of lead, not pictured in Fig. 1, was placed in the beam to reduce the gamma-ray intensity incident on the NE-213. The unfolding of the pulse-height distributions was accomplished using the FERDoR code.

Data

The uncollided transmitted spectra through $\sim 2 \mathrm{ft}$ of sodium, the lead, and the container (density of sodium $=0.0254$ atoms $/ \mathrm{barn} \cdot \mathrm{cm}$ ) as measured by the NE-213 spectrometer system is shown in Fig. 2. The error in the unfolding is such that the spectrum lies somewhere within the darkened area within $68 \%$ confidence limits. In addition, there is an estimated 
ORNL DWG 66-9866R

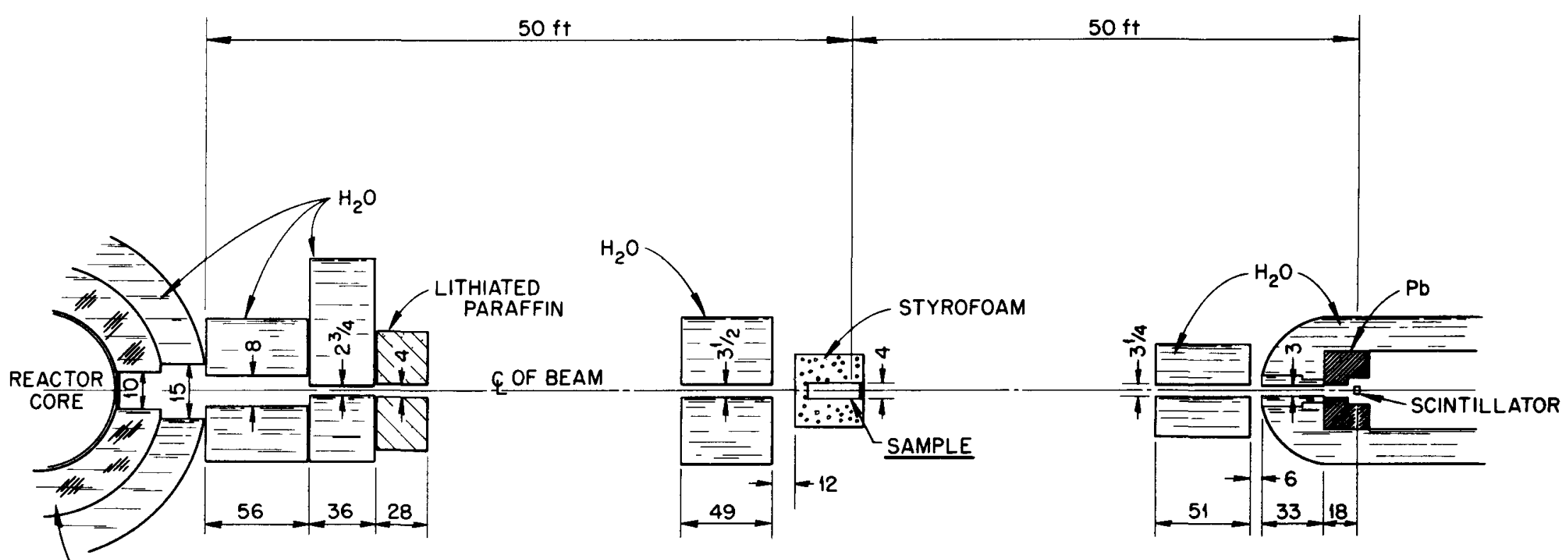

$\mathrm{H}_{2} \mathrm{O}+\mathrm{Pb}$

NOT TO SCALE. ALL DIMENSIONS IN INCHES EXCEPT AS NOTED. BEAM CENTERLINE 78 INCHES ABOVE CONCRETE PAD.

Fig. 1. Schematic of Experimental Arrangement. 


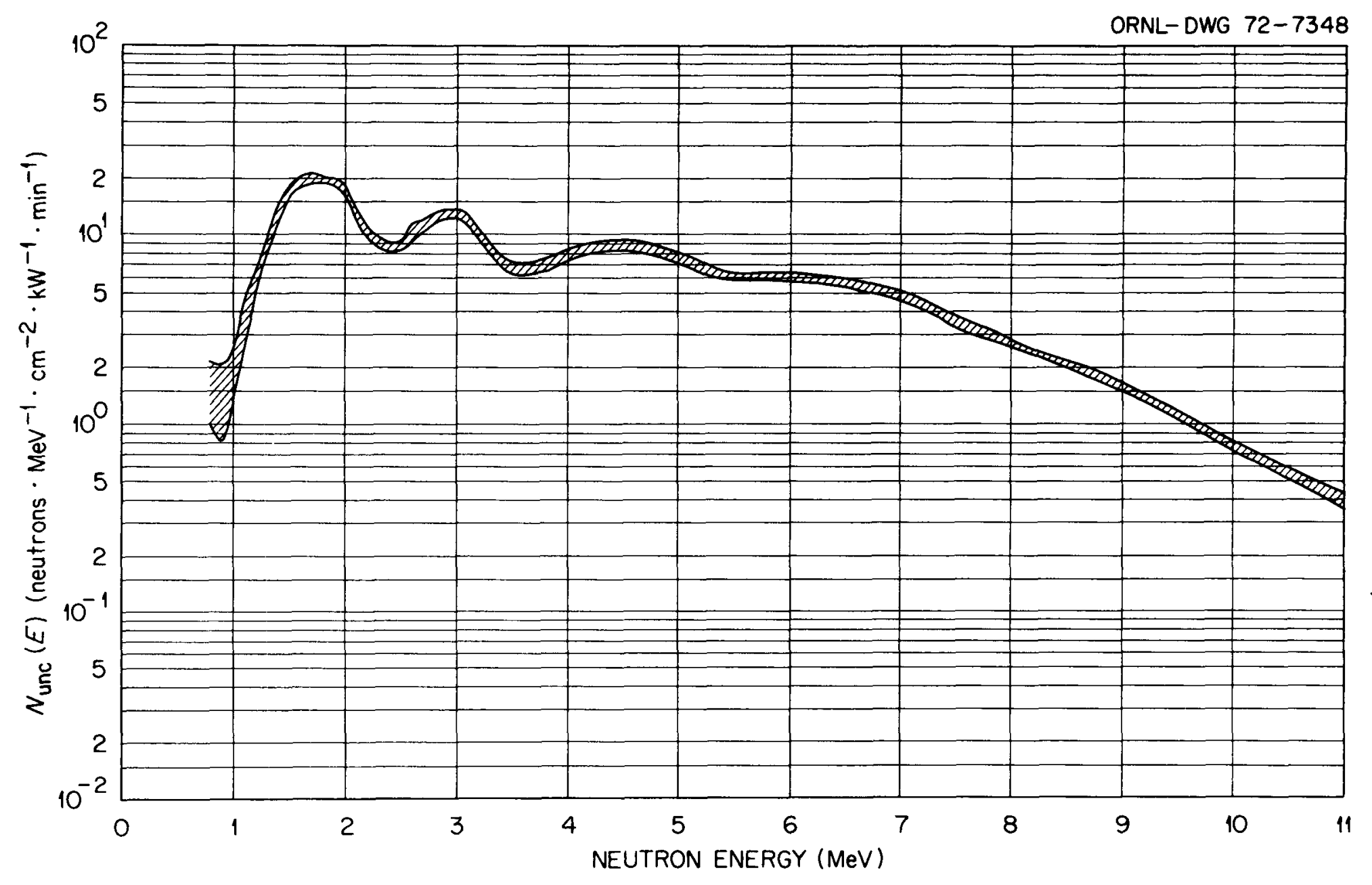

Fig. 2. Transmitted Spectrum Through Sodium. 
$5-10 \%$ error in the absolute measurements due to power calibration uncertainties.

The spectrum measured by the NE-213 at the same location when the sodium is removed from the beam, but with the empty container and lead still in place, is shown in Fig. 3 and tabulated in Table I. The resolution function of the NE-213 spectrometer system and unfolding procedure are shown in Table II, expressed as full width at half maximum (percent of peak energy).

Method of Calculation

The calculation consists first of determining a transmitted uncollided spectrum $N_{u n c}\left(\Delta E^{\prime}\right)$.

$$
N_{\text {unc }}\left(\Delta E^{\prime}\right)=E_{i} \sum_{\text {in } \Delta E^{\prime}} N_{0}\left(E_{i}\right) e^{-\Sigma_{\text {tot }}\left(E_{i}\right) t} \Delta E_{i} / \Delta E^{\prime},
$$

where $N_{0}\left(E_{i}\right)$ is taken or interpolated from Table $I, t=60.56 \mathrm{~cm}$, and the energy intervals $\Delta E_{i}$, which in general may be of variable width, are chosen sufficiently small that all of the structure in the vicinity of all of the minima in the total cross section is included. The total number of energy subintervals, $\Delta \mathrm{E}_{i}$, used in the region $0.5-12 \mathrm{MeV}$ should follow as closely as possible the number suggested in the report sheet. The values of $\mathrm{N}_{\text {unc }}\left(\Delta \mathrm{E}^{\prime}\right)$ are to be binned into far fewer intervals, $\left(\Delta \mathrm{E}^{\prime}\right)$, shown in the attached report sheet.

The second part of the calculation consists of folding the values of $N_{\text {unc }}\left(\Delta E^{\prime}\right)$ with the resolution function of the $N E-213$ spectrometer system:

$$
N_{\text {unc }}(E)=\sum_{E^{\prime}} N_{\text {unc }}\left(\Sigma E^{\prime}\right) R\left(E^{\prime} \rightarrow E\right) \Delta E^{\prime} .
$$




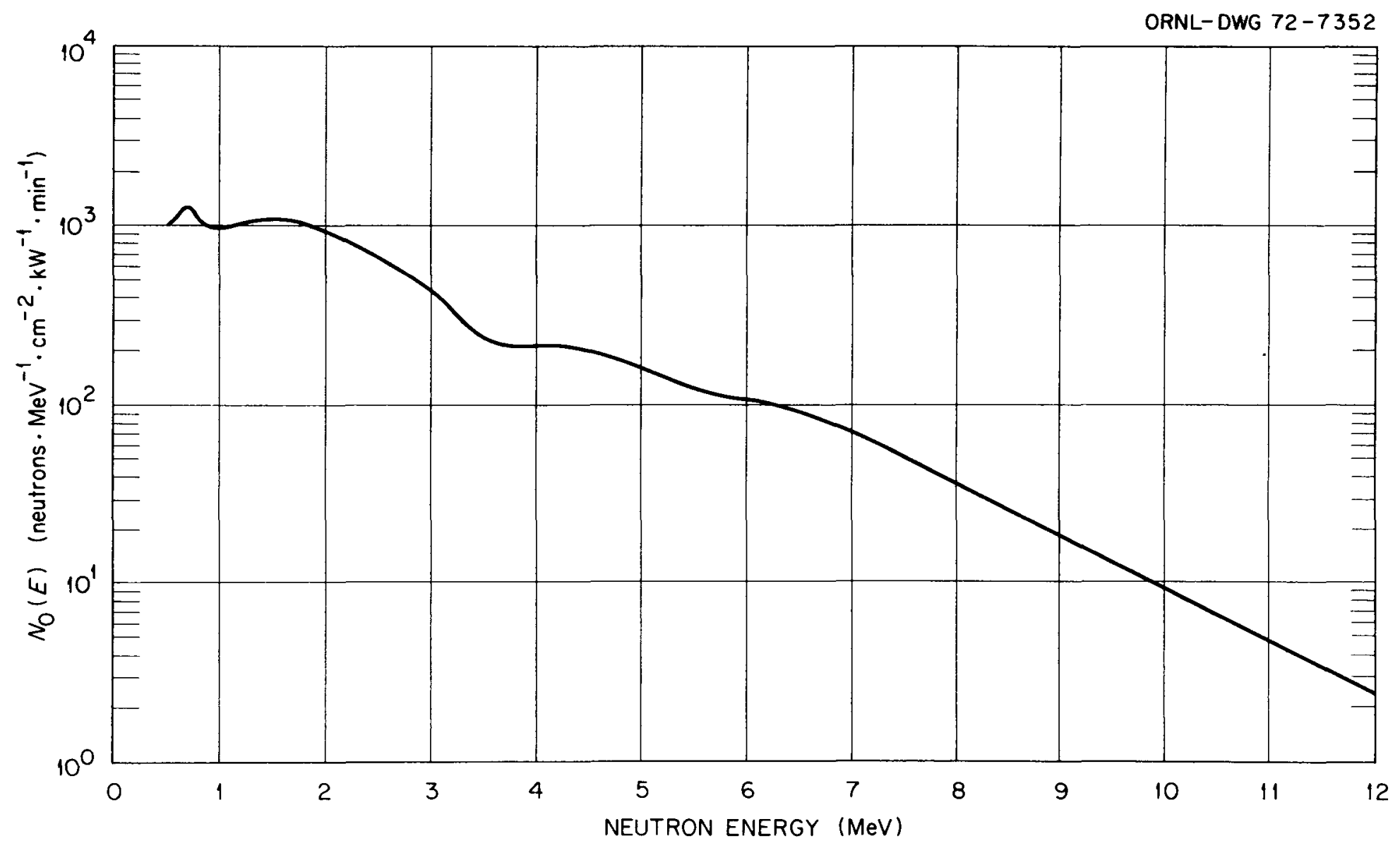

Fig. 3. Source Spectrum for Sodium. 
Table I. Tabulated Source Spectrum (Spectrum Transmitted Through the Lead and Empty Container) in Units of Neutrons $/ \mathrm{MeV} / \mathrm{cm}^{2} / \mathrm{Killowatt} / \mathrm{Min}$ as a Function of Energy in MeV*

\begin{tabular}{|c|c|c|c|c|c|c|c|}
\hline$E$ & $\mathrm{~N}_{0}(\mathrm{E})$ & $\mathrm{E}$ & $\mathrm{N}_{0}(\mathrm{E})$ & $E$ & $\mathrm{~N}_{0}(\mathrm{E})$ & $E$ & $\mathrm{~N}_{0}(\mathrm{E})$ \\
\hline 0.5 & 1010 & 2.2 & 850 & 4.4 & 203 & 8.2 & 32.0 \\
\hline 0.55 & 1045 & 2.3 & 790 & 4.5 & 195 & 8.4 & 28.0 \\
\hline 0.6 & 1105 & 2.4 & 720 & 4.6 & 187 & 8.6 & 24.3 \\
\hline 0.65 & 1205 & 2.5 & 670 & 4.7 & 181 & 8.8 & 21.3 \\
\hline 0.7 & 1240 & 2.6 & 610 & 4.8 & 174 & 9.0 & 19.0 \\
\hline 0.75 & 1180 & 2.7 & 560 & 4.9 & 169 & 9.2 & 16.2 \\
\hline 0.8 & 1045 & 2.8 & 510 & 5.0 & 162 & 9.4 & 14.1 \\
\hline 0.85 & 1020 & 2.9 & 470 & 5.2 & 147 & 9.6 & 12.3 \\
\hline 0.9 & 995 & 3.0 & 425 & 5.4 & 134 & 9.8 & 10.8 \\
\hline 0.95 & 985 & 3.1 & 375 & 5.6 & 122 & 10.0 & 9.5 \\
\hline 1.0 & 975 & 3.2 & 330 & 5.8 & 113 & 10.2 & 8.1 \\
\hline 1.1 & 985 & 3.3 & 290 & 6.0 & 107 & 10.4 & 7.2 \\
\hline 1.2 & 995 & 3.4 & 260 & 6.2 & 101 & 10.6 & 6.3 \\
\hline 1.3 & 1010 & 3.5 & 243 & 6.4 & 94 & 10.8 & 5.4 \\
\hline 1.4 & 1035 & 3.6 & 229 & 6.6 & 86 & 11.0 & 4.7 \\
\hline 1.5 & 1040 & 3.7 & 218 & 6.8 & 79 & 11.2 & 4.1 \\
\hline 1.6 & 1035 & 3.8 & 209 & 7.0 & 72 & 11.4 & 3.6 \\
\hline 1.7 & 1020 & 3.9 & 207 & 7.2 & 63 & 11.6 & 3.2 \\
\hline 1.8 & 985 & 4.0 & 213 & 7.4 & 55 & 11.8 & 2.8 \\
\hline 1.9 & 975 & 4.1 & 214 & 7.6 & 48 & 12.0 & 2.4 \\
\hline 2.0 & 950 & 4.2 & 213 & 7.8 & 42 & & \\
\hline 2.1 & 900 & 4.3 & 209 & 8.0 & 36.5 & & \\
\hline
\end{tabular}

*Interpolation in this table should follow the formula:

$$
N_{0}(E)=\frac{E_{2}-E}{E_{2}-E_{1}} N_{0}\left(E_{1}\right)+\frac{E-E_{1}}{E_{2}-E_{1}} N_{0}\left(E_{2}\right) \text {, where } E_{1} \leq E \leq E_{2} \text {. }
$$


Table II. Energy Resolution of the Spectrometer System*

\begin{tabular}{|c|c|c|c|c|c|}
\hline $\mathrm{E}(\mathrm{MeV})$ & $\begin{array}{c}a \\
\text { FWHM/E }(\%)\end{array}$ & $\mathrm{E}(\mathrm{MeV})$ & $\begin{array}{c}a \\
\text { FWHM/E (\%) }\end{array}$ & $\mathrm{E}(\mathrm{MeV})$ & $\begin{array}{c}\mathrm{a} \\
\text { FWHM/E }(\%)\end{array}$ \\
\hline 0.5 & 47.5 & 3.3 & 18.8 & 6.2 & 13.5 \\
\hline 0.6 & 44 & 3.4 & 18.5 & 6.4 & 13.2 \\
\hline 0.7 & 41 & 3.5 & 18.2 & 6.6 & 13.0 \\
\hline 0.8 & 38.5 & 3.6 & 18.0 & 6.8 & 12.8 \\
\hline 0.9 & 36 & 3.7 & 17.7 & 7.0 & 12.6 \\
\hline 1.0 & 33.5 & 3.8 & 17.4 & 7.2 & 12.4 \\
\hline 1.1 & 32.5 & 3.9 & 17.1 & 7.4 & 12.2 \\
\hline 1.2 & 31 & 4.0 & 16.9 & 7.6 & 12.1 \\
\hline 1.3 & 30 & 4.1 & 16.7 & 7.8 & 11.9 \\
\hline 1.4 & 29 & 4.2 & 16.5 & 8.0 & 11.8 \\
\hline 1.5 & 27.5 & 4.3 & 16.3 & 8.2 & 11.6 \\
\hline 1.6 & 26.5 & 4.4 & 16.1 & 8.4 & 11.5 \\
\hline 1.7 & 26 & 4.5 & 15.9 & 8.6 & 11.4 \\
\hline 1.8 & 25 & 4.6 & 15.7 & 8.8 & 11.3 \\
\hline 1.9 & 24.5 & 4.7 & 15.5 & 9.0 & 11.2 \\
\hline 2.0 & 24 & 4.8 & 15.3 & 9.2 & 11.1 \\
\hline 2.1 & 23.5 & 4.9 & 15.2 & 9.4 & 10.9 \\
\hline 2.2 & 23 & 5.0 & 15.1 & 9.6 & 10.8 \\
\hline 2.3 & 22.5 & 5.1 & 14.9 & 9.8 & 10.7 \\
\hline 2.4 & 22 & 5.2 & 14.7 & 10.0 & 10.5 \\
\hline 2.5 & 21.5 & 5.3 & 14.5 & 10.2 & 10.3 \\
\hline 2.6 & 21.2 & 5.4 & 14.4 & 10.4 & 10.2 \\
\hline 2.7 & 20.8 & 5.5 & 14.3 & 10.6 & 10.1 \\
\hline 2.8 & 20.4 & 5.6 & 14.2 & 10.8 & 10.0 \\
\hline 2.9 & 20.1 & 5.7 & 14.1 & 11.0 & 9.8 \\
\hline 3.0 & 19.7 & 5.8 & 13.9 & 11.4 & 9.7 \\
\hline 3.1 & 19.4 & 5.9 & 13.8 & 11.8 & 9.6 \\
\hline 3.2 & 19.1 & 6.0 & 13.7 & 12.2 & 0.6 \\
\hline
\end{tabular}

*Irterpolation in this table should follow the formula

$$
a(E)=\frac{E_{2}-E}{E_{2}-E_{1}} a\left(E_{1}\right)+\frac{E-E_{1}}{E_{2}-E_{1}} a\left(L_{2}\right)
$$

where $E_{1} \leq E \leq E_{2}$. 
$R\left(E^{\prime} \rightarrow E\right)$ is a gaussian centered at $E^{\prime}$, the midpoint of $\Delta E^{\prime}$, and using the values appearing in Table II, becomes

$$
R\left(E^{\prime} \rightarrow E\right)=\frac{93.944}{a E^{\prime}} \exp -\left\{\left(\frac{\left(E-E^{\prime}\right) \times 235.4820}{E^{\prime} a}\right)^{2} / 2\right\},
$$

where $a$ is the FWHM value at $E^{\prime}$ expressed in the units of Table II. The smeared calculated spectra $N_{\text {unc }}(E)$ may then be compared directly with the reported experimental spectra.

$\underline{\text { Codes }}$

A FORTRAN package is available to perform all the manipulation described in the preceding section. Subroutine XSECT and its subroutines access the total cross section from an $\mathrm{ENDF} / \mathrm{B}$ tape and interpolate the cross section for any energy according to the interpolation scheme specified on the tape. It will only access pointwise data so that any evaluation at least partially described by resonance parameters above $500 \mathrm{keV}$ cannot be accessed by this code. (See Table III.) It will be necessary to obtain a pointwise representation of the same tapes from Brookhaven in this instance. The main routine calculates the uncollided flux, smoothes the uncollided flux with the resolution function of the spectrometer system, and outputs the fluxes both before and after smoothing in the energy grid suggested in the report sheet.

The input data consist of the following cards:

Card A. T, ADEN (12F6.3). T, the thickness of the cylinder in centimeters, and ADEN the atomic density in atoms/barn.cm are shown in the following table (Table III).

Card B. $\operatorname{ELEM}(\mathrm{I}), \mathrm{I}=1,20(20 \mathrm{~A} 4)$. $\operatorname{ELEM}(\mathrm{I})$ is the element studied (see Table III). 
Table III. Parameters Describing the Sodium Broomstick Experiment and the ENDF/B Evaluations Used to Compare with Experiment

\begin{tabular}{lllll} 
ELEM(I) & T & ADEN & MATN $\emptyset$ & COMMENTS : \\
S $\$ D I U M$ & 60.56 & 0.0254 & 1156 & $\begin{array}{l}\text { Resonance parameters } \\
\text { used, but only below } \\
\end{array}$ \\
& & & $150 \mathrm{keV}$. OK \\
\hline
\end{tabular}


Card C. MATN $\varnothing$, MDDE, NDFB(12I6). MATN $\varnothing$ is the MAT number of the ENDF/B evaluation (see Table III), MDDE $=1$ if binary, $=2$ if $\mathrm{BCD}$, and depends on the particular version of the tape an installation possesses, and NDFB is the logical tape number of the ENDF/B tape.

Cards D. ERG(I), I=1,86(12F6.3). The energy values in MeV at which the source is tabulated in Table I. $\operatorname{ERG}(1)=0.50$ and $\operatorname{ERG}(86)=12.0$.

Cards E. FZER $\emptyset(\mathrm{I}), \mathrm{I}=1,86(12 \mathrm{~F} 6.3)$. The source spectrum in units of neutrons $/ \mathrm{MeV} / \mathrm{cm}^{2} /$ kilowatt $/ \mathrm{min}$ tabulated in Table I. $\operatorname{FZER} \varnothing(1)=1010$ and $\operatorname{FZER} \emptyset(86)=2.4$.

Cards F. NINT(I), $I=1,85(1216)$. The number of subintervals $\Delta E_{i}$ within each $\Delta E^{\prime}$ used in calculating the uncollided flux (see report sheet). Use the suggested values appearing in the report sheet. $\operatorname{NINT}(1)=50$ and $\operatorname{NINT}(85)=10$.

Cards G. $E R(I), I=1,84(12 \mathrm{~F} 6.3)$. The energy value in $\mathrm{MeV}$ at which the resolution function of the spectrometer system is specified in Table II. $\operatorname{ER}(1)=0.50$ and $E R(84)=12.2$.

Cards H. PCTWID(I) , I=1,84(12F6.3). The values of a, the resolution of the spectrometer system, in units of percent of peak energy of the full width at half maximum, also tabulated in Table II. PCTWID $(1)=47.5$ and $\operatorname{PCTWID}(84)=9.6$.

Cards I. ES(I), I=1,75(12F6.3). The energy values in MeV at which the smoothed uncollided spectrum is to be calculated (see the report sheet). $\operatorname{ES}(1)=0.80$ and $\operatorname{ES}(75)=11.0$. 
The code requires a storage of approximately $92 \mathrm{~K}$ bytes ( $23 \mathrm{~K}$ words) on the IBM-360/75 or $360 / 91$ computer with a running time of approximately $25 \mathrm{sec}$ on the IBM-360/91. 
Report sheet for the sodium "broomstick" experiment.

Calculated values of $N_{\text {unc }}\left(\Delta E^{\prime}\right)$ and approximate number of subintervals $\Delta E_{i}$ for each $\Delta \mathrm{E}^{\prime}$ used.

\begin{tabular}{|c|c|c|c|c|c|}
\hline $\begin{array}{l}\Delta E^{\prime} \\
(\mathrm{MeV})\end{array}$ & $\begin{array}{c}\mathrm{N}_{\text {unc }}\left(\Delta \mathrm{E}^{\prime}\right) \\
\text { (neut } / \mathrm{cm}^{2} / \mathrm{MeV} / \\
\mathrm{kW} / \mathrm{min} \text { ) }\end{array}$ & $\begin{array}{c}\text { Number of } \\
\text { Subintervals } \\
\Delta E^{\prime} / \Delta E_{1}\end{array}$ & $\begin{array}{l}\Delta E^{\prime} \\
(\mathrm{MeV})\end{array}$ & $\begin{array}{c}\mathrm{N}_{\text {unc }}\left(\Delta \mathrm{E}^{\prime}\right) \\
\text { (neut } / \mathrm{cm}^{2} / \mathrm{MeV} / \\
\mathrm{kW} / \mathrm{min} \text { ) }\end{array}$ & $\begin{array}{c}\text { Number of } \\
\text { Subintervals } \\
\Delta E^{\prime} / \Delta E_{i}\end{array}$ \\
\hline $0.50-0.55$ & & 50 & $2.8-2.9$ & & 50 \\
\hline $0.55-0.60$ & & 50 & $2.9-3.0$ & & 50 \\
\hline $0.60-0.65$ & & 50 & $3.0-3.1$ & & 50 \\
\hline $0.65-0.70$ & & 50 & $3.1-3.2$ & & 50 \\
\hline $0.70-0.75$ & & 50 & $3.2-3.3$ & & 50 \\
\hline $0.75-0.80$ & & 50 & $3.3-3.4$ & & 50 \\
\hline $0.80-0.85$ & & 50 & $3.4-3.5$ & & 50 \\
\hline $0.85-0.90$ & & 50 & $3.5-3.6$ & & 50 \\
\hline $0.90-0.95$ & & 50 & $3.6-3.7$ & & 50 \\
\hline $0.95-1.0$ & & 50 & $3.7-3.8$ & & 50 \\
\hline $1.0-1.1$ & & 50 & $3.8-3.9$ & & 50 \\
\hline $1.1-1.2$ & & 50 & $3.9-4.0$ & & 50 \\
\hline $1.2-1.3$ & & 50 & $4.0-4.1$ & & 50 \\
\hline $1.3-1.4$ & & 100 & $4.1-4.2$ & & 50 \\
\hline $1.4-1.5$ & & 100 & $4.2-4 \cdot 3$ & & 50 \\
\hline $1.5-1.6$ & & 100 & $4.3-4.4$ & & 50 \\
\hline $1.6-1.7$ & & 100 & $4.4-4.5$ & & 50 \\
\hline $1.7-1.8$ & & 100 & $4.5-4.6$ & & 50 \\
\hline $1.8-1.9$ & & 100 & $4.6-4.7$ & & 50 \\
\hline $1.9-2.0$ & & 100 & $4.7-4.8$ & & 50 \\
\hline $2.0-2.1$ & & 100 & $4.8-4.9$ & & 50 \\
\hline $2.1-2.2$ & & 100 & $4.9-5.0$ & & 50 \\
\hline $2.2-2.3$ & & 100 & $5.0-5.2$ & & 50 \\
\hline $2.3-2.4$ & & 100 & $5.2-5.4$ & & 50 \\
\hline $2.4-2.5$ & & 100 & $5.4-5.6$ & & 50 \\
\hline $2.5-2.6$ & & 100 & $5.6-5.8$ & & 50 \\
\hline $2.6-2.7$ & & 50 & $5.8-6.0$ & & 50 \\
\hline $2.7-2.8$ & & 50 & $6.0-6.2$ & & 50 \\
\hline
\end{tabular}


Report sheet for the sodium "broomstick" experiment (continued). Calculated values of $\mathrm{N}_{\text {unc }}\left(\Delta E^{\prime}\right)$ and approximate number of subintervals $\Delta E_{i}$ for each $\Delta \mathrm{E}^{\prime}$ used.

\begin{tabular}{|c|c|c|c|c|c|}
\hline $\begin{array}{l}\Delta E^{\prime} \\
(\mathrm{MeV})\end{array}$ & 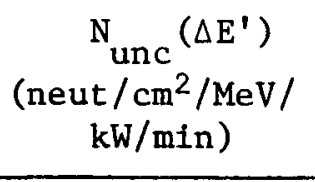 & $\begin{array}{c}\text { Number of } \\
\text { Subintervals } \\
\Delta E^{\prime} / \Delta E_{i}\end{array}$ & $\begin{array}{c}\Delta \mathrm{E}^{\prime} \\
(\mathrm{MeV})\end{array}$ & $\begin{array}{c}\mathrm{N}_{\text {unc }}\left(\Delta \mathrm{E}^{\prime}\right) \\
\text { (neut } / \mathrm{cm}^{2} / \mathrm{MeV} / \\
\mathrm{kW} / \mathrm{min})\end{array}$ & $\begin{array}{c}\text { Number of } \\
\text { Subintervals } \\
\Delta E^{\prime} / \Delta E_{i}\end{array}$ \\
\hline $6.2-6.4$ & & 50 & $9.6-9.8$ & & 20 \\
\hline $6.4-6.6$ & & 30 & $9.8-10.0$ & & 20 \\
\hline $6.6-6.8$ & & 30 & $10.0-10.2$ & & 10 \\
\hline $6.8-7.0$ & & 30 & $10.2-10.4$ & & 10 \\
\hline $7.0-7.2$ & & 30 & $10.4-10.6$ & & 10 \\
\hline $7.2-7.4$ & & 30 & $10.6-10.8$ & & 10 \\
\hline $7.4-7.6$ & & 30 & $10.8-11.0$ & & 10 \\
\hline $7.6-7.8$ & & 30 & $11.0-11.2$ & & 10 \\
\hline $7.8-8.0$ & & 30 & $11.2-11.4$ & & 10 \\
\hline $8.0-8.2$ & & 20 & $11.4-11.6$ & & 10 \\
\hline $8.2-8.4$ & & 20 & $11.6-11.8$ & & 10 \\
\hline $8.4-8.6$ & & 20 & $11.8-12.0$ & & 10 \\
\hline $8.6-8.8$ & & 20 & & & \\
\hline $8.8-9.0$ & . & 20 & & & \\
\hline $9.0-9.2$ & & 20 & & & \\
\hline $9.2-9.4$ & & 20 & & & \\
\hline $9.4-9.6$ & & 20 & & & \\
\hline
\end{tabular}


Report sheet for the sodium "broomstick" experiment (continued).

Calculated values of $N_{u n c}(E)$, i.e., smoothed data to be compared with experiment.

\begin{tabular}{|c|c|c|c|c|c|}
\hline $\mathrm{E}(\mathrm{MeV})$ & $\begin{array}{c}\mathrm{N}_{\text {unc }}(\mathrm{E}) \\
\text { (neut } / \mathrm{cm}^{2} / \mathrm{MeV} / \\
\mathrm{kW} / \mathrm{min} \text { ) } \\
\end{array}$ & $\mathrm{E}(\mathrm{MeV})$ & $\begin{array}{c}\mathrm{N}_{\text {unc }}(\mathrm{E}) \\
\text { (neut } / \mathrm{cm}^{2} / \mathrm{HieV} / \\
\mathrm{kW} / \mathrm{min} \text { ) }\end{array}$ & $\mathrm{E}(\mathrm{MeV})$ & $\begin{array}{c}\mathrm{N}_{\text {unc }}(\mathrm{E}) \\
\text { (neut } / \mathrm{cm}^{2} / \mathrm{MeV} / \\
\mathrm{kW} / \mathrm{min} \text { ) }\end{array}$ \\
\hline 0.8 & & 3.1 & & 6.2 & \\
\hline 0.85 & & 3.2 & & 6.4 & \\
\hline 0.9 & & 3.3 & & 6.6 & \\
\hline 0.95 & & 3.4 & & 6.8 & \\
\hline 1.0 & & 3.5 & & 7.0 & \\
\hline 1.1 & & 3.6 & & 7.2 & \\
\hline 1.2 & & 3.7 & - & 7.4 & \\
\hline 1.3 & & 3.8 & & 7.6 & \\
\hline 1.4 & & 3.9 & & 7.8 & \\
\hline 1.5 & & 4.0 & & 8.0 & \\
\hline 1.6 & & 4.1 & & 8.2 & \\
\hline 1.7 & & 4.2 & & 8.4 & \\
\hline 1.8 & & 4.3 & & 8.6 & \\
\hline 1.9 & & 4.4 & - & 8.8 & \\
\hline 2.0 & & 4.5 & & 9.0 & \\
\hline 2.1 & & 4.6 & 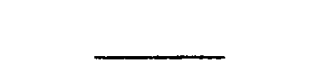 & 9.2 & \\
\hline 2.2 & & 4.7 & & 9.4 & \\
\hline 2.3 & & 4.8 & - & 9.6 & \\
\hline 2.4 & & 4.9 & & 9.8 & \\
\hline 2.5 & & 5.0 & & 10.0 & \\
\hline 2.6 & & 5.2 & & 10.2 & \\
\hline 2.7 & & 5.4 & & 10.4 & \\
\hline 2.8 & 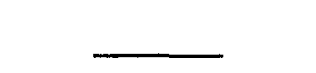 & 5.6 & 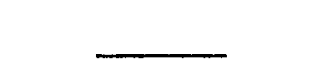 & 10.6 & - \\
\hline 2.9 & & 5.8 & & 10.8 & \\
\hline 3.0 & & 6.0 & & 11.0 & \\
\hline
\end{tabular}




\section{INTERNAL DISTRIBUTION}

1-3. L. S. Abbott

4. A. R. Buhl

5-9. C. E. Clifford

10. M. L. Gritzner

11. W. O. Harms

12. R. E. Maerker

13. F. C. Maienschein

14. B. J. McGregor

15. F. R. Mynatt

16. E. M. Oblow

17. F. G. Perey

18. R. W. Roussin

19. A. H. Snell

20. D. B. Trauger
21. D. K. Trubey

22. G. E. Whitesides

23-72. Radiation Shielding Info. Ctr.

73. H. Feshbach (consultant)

74. H. Goldstein (consultant)

75. C. R. Mehl (consultant)

76. H. T. Motz (consultant)

77-78. Central Research Library

79. ORNL Y-12 Technical Library Document Reference Section

80-82. Laboratory Records

83. Laboratory Records ORNL RC

84. ORNL Patent Office

\section{EXTERNAL DISTRIBUTION}

85. H. Alter, Atomics International, 8900 Desota St., Box 309, Canoga Park, Calif. 91304

86. Martin Becker, Rensselaer Polytechnical Institute, Tibbits Ave., Troy, N. Y. 12181

87. R. Danne1s, Westinghouse Electric Corp., ARD, Waltz Mill Site, P. O. Box 158, Madison, Pa. 15663

88. M. Drake, Brookhaven National Laboratory, , Upton, N. Y. 11973

89. N. Francis, Knolls Atomic Power Laboratory, Schenectady, N. Y. 12301

90. R. A. Grimesey, Idaho Nuclear Corp., P. 0. Box 1845, Idaho Falls, Idaho 83401

91. W. H. Hannum, Division of Reactor Development \& Technology, U. S. Atomic Energy Commission, Washington, D. C. 20545

92. L. Harris, Gulf General Atomic, P. 0. Box 608, San Diego, Calif. 92112

93. P. B. Hemmig, Division of Reactor Development \& Technology, U. S. Atomic Energy Commission, Washington, D. C. 20545

94. B. Hutchins, General Electric Co., BRDO, 310 DeGuigne Dr., Sunnyvale, Calif. 94086

95. M. H. Kalos, Courant Institute of Mathematical Sciences, New York University, 251 Mercer St., New York, N. Y. 10012

96. D. C. Kau1, Defense Nuclear Agency, Washington, D. C. 20305

97. R. J. LaBauve, Los Alamos Scientific Laboratory, P. 0. Box 1663, Los Alamos, N. M. 87544

98. K. 0. Laughon, AEC Site Rep., ORNL

99. Duane Marr, WADCO, P. O. Box 1970, Richland, Wash. 99352

100. Malcolm McGregor, Lawrence Livermore Laboratory, Berkeley, Calif. 94720

101. S. Pearlstein, Brookhaven National Laboratory, Upton, N. Y. 11973

102. T. A. Pitterle, Westinghouse Electric Corp., ARD, Waltz Mill Site, P. 0. Box 158, Madison, Pa. 15663

103. D. L. Rigotti, U. S. Army Nuclear Defense Laboratory, P. O. Box 856 Edgewood Arsenal, Md. 
104. E. Specht, Atomics International, 8900 Desota St., Box 309, Canoga Park, Calif. 91304

105. E. A. Straker, Science Applications, Inc., Clinton Bldg., Suite 700, 2109 W. Clinton Ave., Huntsville, Ala. 35805

106. A. Trave11i, Argonne National Laboratory, 9700 S. Cass Ave., Argonne, I11.

107-108. Technical Information Center (TIC)

109-110. Research and Technical Support Division 